\title{
Synthesis of Bifunctional Chelating Agent Derived from Lysine and its Radiolabeling with ${ }^{99 \mathrm{~m}} \mathrm{Tc}$
}

\author{
Mi-Sun Pyun, Kang-Hỵuk Choi, Young-Don Hong, and Sun-Ju Choi* \\ Radioisotope Research and Development Division, Nuclear Basic Science Department, \\ Korea Atomic Energv Research Institute, Daejon 305-353, Korea. E-mail: choisjáakaerire.kr \\ Received Jantary 24, 2009, Accepted March 18, 2009
}

Key Words: BFCA, DTPA derivatives. Lysine, ${ }^{99 \mathrm{~m}} \mathrm{Tc}$

Several types of chelating agents for radiometal ion complexes have been proposed for use as both radiotracers and in radiotherapy, and for paramagnetic metal ion complexes used as MRI contrast-enhancing agents. ${ }^{1-t}$ In the past decade, bifunctional chelating agents (BFCAs) have received increasing interest because of their important role in a successful application of bioactive molecule-based metal complexes for the forementioned purposes. ${ }^{5-6}$ Functionalized EDTA as a BFCA was first used for evaluating a scintigraphy. but this metal complex revealed a low stability for a $i n$ wivo condition. ${ }^{4-9}$ Other bifunctionalized cyclic chelating agents based on oligoaza macrocycle derivatives such as $\mathrm{MeO}$ DOTA-NCS ( $\alpha$-(5-isothiocyanato-2-methoxyphenyl)-1 , 4, 7, 10tetraazacyclododecane-1,4.7,10-tetraacetic acid). 2B-DOTANCS (2-(p-isothiocy anatobenzyl)-1.4.7.10-tetraazacy clododecane-1.4.7.10-tetraacetic acid). TEPPA (1.4.8.11-tetraazacyclotetradecan-1,4.8.11-tetrapropionic acid). and so on were then introduced and are now commercially available.$^{1(i)-2}$ The functionalized pendant-amms of oligoaza derivatives can be utilized to conjugate bioactive molecules. ${ }^{13}$ and their complexes with metal ions show a better stability than acyclochelating agents. However. despite their good properties. forming a metal complex demands an incubation of about 0.5 hr $-2 \mathrm{hrs}$, and, at times. a high temperature. Therefore. we have concentrated on the development of new BFCAs which have a higher affinity and stability to almost all kinds of lanthanides ions using diethỵlene triamine pentaacetic acid (DTPA). We previously reported on a sy'nthetic method for DTPA derivatives whose original moiety are intact by using cysteine. ${ }^{1+4}$ In line with the DTPA series, another DTPA derivative is introduced for a simple amide coupling with a $\mathrm{C}$-terminal in bioactive peptides or small molectules. Therefore we have designed another DTPA based on a lysine backbone and focused on reducing the steps for a easier preparation of their DTPA derivative in addition to increasing the yield. In this paper, we describe the preparation and radiolabeling of lysine-based DTPA with one of the most ideal ( $140 \mathrm{keV} \gamma$ emission, $t_{1: 2}=6 \mathrm{~h}$ ) and cost-effective radioisotopes for a nuclear imaging. ${ }^{9{ }^{9 n}} \mathrm{Tc}$

\section{Experimental Section}

Instruments and materials. The NMR spectra were recorded by Bruker Avance $500\left(500 \mathrm{MHz} .{ }^{1} \mathrm{H}\right.$. KRICT. Daejeon) with a ppm unit ratio versus TMS $(\delta=0)$ as an internal standard.
Mass spectra were measured with the Hewlett Packard HP 1100 series LC/MDS (Chungnam National Univ.). Colunun purifications were performed with CombiFlash ${ }^{\mathrm{R}}$ (Teledyn Isco. Inc.) and RediSep ${ }^{i \mathrm{E} i}$ silica colunn. Sodium pertechnetate $\left(\left[{ }^{99 \mathrm{~m}} \mathrm{Tc}\right] \mathrm{NaTcO}_{4}\right.$ ) was obtained from a ${ }^{99} \mathrm{Mo}^{-99 \mathrm{Tm}} \mathrm{Tc}$ generator (Sam Young Unitech Co.. LTD.). Radioactivities were measured by using an ionizing chamber (Atomlab 200. Bio-dex) and the radiolabeling yield was determined by an ITLC scanner (Trance maste 200 . Berthold). All the chenicals and reagents used in this study were analytical grade and purchased from Aldrich, and used without any further purification

$N_{\varepsilon}$-(tert-Butoxycarbonyl)-L-lysine methylester(1). From a) procedure: To a suspension of $\mathrm{L}-\mathrm{ly}$ sine $(5.5 \mathrm{mmol})$ in $\mathrm{CH}_{3} \mathrm{OH}$. chlorotrimethylsilane (19.2 mnol) was dropwisely added for 10 min. After stirring for 24 hrs. the reaction mixture was evaporated in vacuo to give the crude product as a white powder. Without any further purification. the crude product was dissolved in 2 drops of water $\mathrm{CH}_{3} \mathrm{OH}$, and triethylamine. solution of di-tert-butyl-dicarbonate $(6.0 \mathrm{mmol})$ in $\mathrm{CH}_{2} \mathrm{Cl}_{2}$ was added for $10 \mathrm{~min}$ under $-10^{\circ} \mathrm{C}$ and stirred overnight. The reaction mixture was reduced the volume until $3 \mathrm{~nL}$ and purified with flash column chromatography with gradient condition $\left(\mathrm{CH}_{2} \mathrm{Cl}_{2} / \mathrm{CH}_{2} \mathrm{OH} 95: 5\right.$ then $\left.80: 20\right)$ to give a product with $86 \%$ yield.

Lysine methylester (Intermediate): ${ }^{1} \mathrm{H}$ NMR $\left(\mathrm{CD}_{3} \mathrm{OD}\right) \delta$ $1.58(\mathrm{~m} .2 \mathrm{H}) .1 .73$ (p. $2 \mathrm{H}), 1.98(\mathrm{~m}, 2 \mathrm{~N}) .2 .99$ (t. $2 \mathrm{H}) .3 .89$ (s. $3 \mathrm{H})$, 4.11 (t. IH) (LC/MSD M+1): cald. for 260.17 found 260.9 .

$N_{e}$-(tert-Butoxycarbonyl)-L-lysine methylester. ${ }^{1} \mathrm{H}$ NMR $\left(\mathrm{CDCl}_{3}\right)$ ò 1.43 (s. 9H). $1.49(2 \mathrm{H}) .1 .53(\mathrm{~m}, 2 \mathrm{H}) .1 .63$ (br m. lH). 1.76 (brm. IH). 3.11 (d. $2 \mathrm{H}) .3 .5 \mathrm{l}(\mathrm{s} . \mathrm{IH}) .3 .72(\mathrm{~s} .3 \mathrm{H})$. 4.62 (t. $1 \mathrm{H}$ ) (LC/MSD M+1): cald. for 260.17 found 260.7 .

From b) procedure: A solution of diazomethane $(35$ numol) ${ }^{15.16}$ in diethyl ether $(30$ nmol) was added cautiously portionwise to a stirred solution of $\mathrm{N}_{\varepsilon}$-(tert-butoxycarbonyl)L-lysine $(4.1 \mathrm{mmol})$ in $\mathrm{CH}_{3} \mathrm{OH}$ under $0{ }^{\circ} \mathrm{C}$. The reaction nixture was maintained under $\mathrm{N}_{2}$ condition and stirred at room temperature for 4 hrs. Evaporation of the solvent under reduced pressure gave the product with quantitative yield.

$\mathrm{N}_{\varepsilon}$-(tert-Butoxycarbonyl)-L-lysine methylester: ${ }^{\mathrm{H}} \mathrm{H}$ NMR $\left(\mathrm{CDCl}_{3}\right) \delta 1.43(\mathrm{~s}, 9 \mathrm{H}), 1.49(2 \mathrm{H}), 1.53(\mathrm{~m}, 2 \mathrm{H}), 1.63(\mathrm{br} \mathrm{m}$, lH). 1.76 (br m. IH). 3.11 (d. $2 \mathrm{H}) .3 .5 \mathrm{l}$ (s. IH). 3.72 (s. $3 \mathrm{H}$ ). 4.62 (t. IH) (LC/MSD M+1): cald. for 260.17 found 260.7 .

$N_{\varepsilon}$-(tert-Butoxycarbony))-L-Lys(tBu-DTPA) methylester (2). To $14(3.1 \mathrm{mmol})$ dissolved in $\mathrm{CH}_{3} \mathrm{CN}$ and DMF. Two molar phosphate buffer $(\mathrm{pH}=8)$ and $\mathrm{cpd} 2(10.7 \mathrm{mmol})$ pre- 
Table 1. Logarithms of the equilibrium quotients at the $1: 1$ metal ion complexes

\begin{tabular}{lcccccc}
\hline & \multicolumn{4}{c}{ Metal ion and Formation constant(Log K, 20 ${ }^{\circ} \mathrm{C}$ ) } \\
\cline { 2 - 6 } & $\mathrm{Y}^{3-}$ & $\mathrm{Sm}^{3-}$ & $\mathrm{Ho}^{3+}$ & $\mathrm{Er}^{3+}$ & $\mathrm{Lu}^{3+}$ & $\mathrm{Dy}^{3-}$ \\
\hline DTPA (diethylentetrianine pentaacetic acid) & 22.13 & 22.44 & 22.88 & 22.83 & 22.60 & 22.92 \\
EDTA (ethylenediamine tetraacetic acid) & 18.09 & 17.14 & 18.62 & 18.85 & 19.83 & 18.30 \\
CDTA (trans-1,2-cyclohexylentedinitrilo tetraacetic acid) & 19.85 & 19.08 & 20.6 & 21.38 & 22.21 & 20.39 \\
\hline
\end{tabular}

pared as previously reported was added. The resulting mixture was vigorously stirred for $48 \mathrm{hrs}$ at room temperature. Organic layer was extracted with $\mathrm{CH}_{2} \mathrm{Cl}_{2}$ and repeated three times. The solvent was evaporated to afford a residue as pale yellow oil form. Purification was performed with flash column chromatography with gradient condition (Hexane/Ethylacetate. from $100: 0$ to $0: 100$ during the $30 \mathrm{~min}$ ) to give a pale oil form product with $76 \%$ yield. ${ }^{3} \mathrm{H}$ NMR $\left(\mathrm{CDCl}_{3}\right) \delta 1.43(5,9 \mathrm{H})$. 1. 46 (s. $36 \mathrm{H}), 1.49 \sim 1.6(\mathrm{~mm}, 6 \mathrm{H}) .2 .88$ (br $8 \mathrm{H}) .3 .11$ (br $2 \mathrm{H}$ ). 3.43 (s. 8H). $3.51(\mathrm{~s}, 1 \mathrm{H}) .3 .70(\mathrm{~s}, 3 \mathrm{H}) .4 .62(\mathrm{t} .1 \mathrm{H})(\mathrm{LC} / \mathrm{MSD}$ $\mathrm{M}+1)$ : cald. for 802.53 found 803.2 .

Hydrolysis (3). Hydrolysis was performed with $3 \mathrm{~N}-\mathrm{HCl}$ at $100^{\circ} \mathrm{C}$ for 20 mins. After evaporation. recrystalization was performed by using $\mathrm{CH}_{3} \mathrm{OH}$ and diethyylether. ${ }^{1} \mathrm{H}$ NMR $\left(\mathrm{CDCl}_{3}\right) \delta 1.48(\mathrm{~m} .2 \mathrm{H}) .1 .71(\mathrm{~m} .+\mathrm{H}) .1 .90(\mathrm{~m}, 2 \mathrm{H}), 3.0 \sim 3.7$ (m. 9H). 3.92 (s. $8 \mathrm{H}$ ) (LC/MSD M-I): cald. for $46+.21$ found $+6+0$.

Preparation of the ${ }^{99 \mathrm{~m}}$ Tc-DTPA complex. After the preparation of $2 \mathrm{mg}$ of $\mathrm{SnCl}_{2}$ dissolved in $0.1 \mathrm{~N} \mathrm{HCl}(1 \mathrm{~mL})$ under inert atmosphere, $0.1 \mathrm{~mL}$ of $\mathrm{SnCl}_{2}$ solution was added to another vial containing $0.5 \mathrm{mg}$ DTPA in $\mathrm{N}_{2}$ purged $\mathrm{HCl}$ solution $(1 \mathrm{~mL} . \mathrm{pH}=5)$ and then $0.2 \mathrm{~mL}$ of freshly eluted $99 \mathrm{mTcO}_{4}^{-}$(3 $\mathrm{mCi}$ ) from ${ }^{59} \mathrm{Mo}-{ }^{59 \mathrm{~m}} \mathrm{Tc}$ generator was added. The reaction mixture was shaken for $10 \mathrm{~min}$ at room temperature and filtered through $0.22 \mu \mathrm{L}$ membrane filter. ITLC test revealed labeling yield as $98 \%$.

\section{Results and Discussion}

Developing new BFCAs that can coordinate easily with metal ions and last for a long time. is one of our on going projects in oder to introduce radiometal ions to bioactive molecules such as peptides. antibodies. and drugs. DTPAs and oligoaza macrocycles are the most common candidate compounds for developing novel BFCA. We first developed a new BFCA related with DTPA because DTPA forms more stable complexes with heayy metal ions by up to $3 \sim 4$ orders of a magnitude compared with EDTA or CDTA (Table 1). ${ }^{\text {? }}$ In addition to this. DTPA is more effective than oligoaza macrocycle for the reaction kinetics. Namely, it may not need a high temperature and a long incubation time for the formation of the complex.

In order to introduce functional groups to DTPA, we designed BFCAs by using functionalized amine. lysine was used in this paper as the supporting body for the DTPA derivative. The preparation scheme and chemical structures of all the intermediate compounds are depicted in Scheme 1. $N_{c}$ (tert-butoxycarbonyl)-L-lysine methylester (1) was synthesised from b) procedure with metlylation by using diazald in oder to protect against Boc-hydrolysis. Diazomethane was prepared according to F. Anndt's report and used 8-fold excess amounts to provide quantitative methylester without any other side products in a methanol solvent. We also prepared 1 by using a) one-pot procedure including methylation and a N-Boc protection. Carboxyl methylester was performed under a methanol solvolysis with $3.5 \mathrm{eq}$ TMS-Cl and a selective $N_{\varepsilon}-$ Boc protection was achieved using (Boc) $)_{2} \mathrm{O}\left(1\right.$ leq) at $-10^{\circ} \mathrm{C}$ with a triethylamine solvent. The data revealed consistent results checked by NMR, IR and TLC. 2 was prepared by using our previous report but we didn't get satisfactory results for the yield. Thus a small anount DMF as a phase catalyst was used to provide 2 with a $76 \%$ yield. For the labeling, we chose ${ }^{g / n 1}$ Tc because DTPA shows specific binding efficiency for heavy metals and ${ }^{99 \mathrm{~m}} \mathrm{Tc}$-DTPAs have also been used in a clinical application such as renal studies for providing both anatonical and functional information a determination of the GFR, to locally image infammatory bowel disease and others. $^{18}$ Tc-DTPA derivative complex was prepared by simply mixing ${ }^{99 \pi} \mathrm{Tc}, \mathrm{SnCl}_{2}$, and DTPA derivative at room temperature in $\mathrm{HCl}$ solution $(\mathrm{pH}=5)$. To determine the amount of ${ }^{99 \mathrm{~m}} \mathrm{TcO}_{4}^{-}$, the sample was cluromatographed on ITLC-SG (Gelman Sciences Ins. USA) using MEK as a mobile phase. Unbounded ${ }^{4 / 111} \mathrm{TCO}_{4}{ }_{4}^{-}$migrated with the solvent front. whereas ${ }^{99 \mathrm{~m}} \mathrm{TcO}_{2}$ and the labeled material remained at
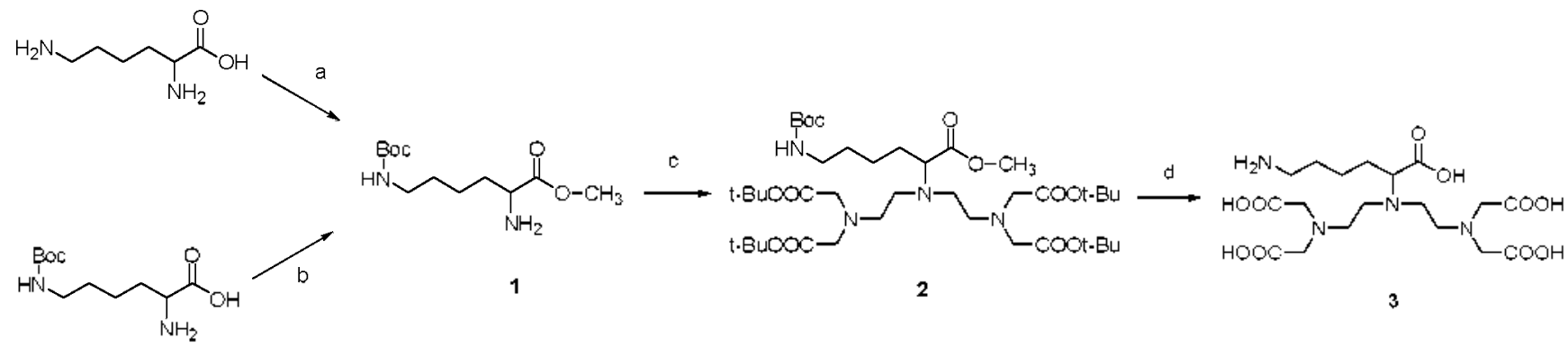

Scheme 1. Reaction pathway for lysine-based DTPA. Reagent and condition; (a) i) TMS-Cl/CH $\mathrm{CH}_{3} \mathrm{OH} / \mathrm{RT}, 24$ hrs; ii) (Boc) $)_{2} \mathrm{O} / \mathrm{CH} \mathrm{H}_{3} \mathrm{OH}$, TEA/ $0^{\circ} \mathrm{C}, 12 \mathrm{hrs}$; (b) Diazomethane/ $\mathrm{CH}_{3} \mathrm{OH} /-10^{\circ} \mathrm{C}, 4 \mathrm{hrs}$; (c) cpd 1/phosphate buffer $\mathrm{pH}=8 \mathrm{RT}, 48 \mathrm{hrs}$; (d) $3 \mathrm{~N}-\mathrm{HCl} / 100^{\circ} \mathrm{C}, 20$ mins 

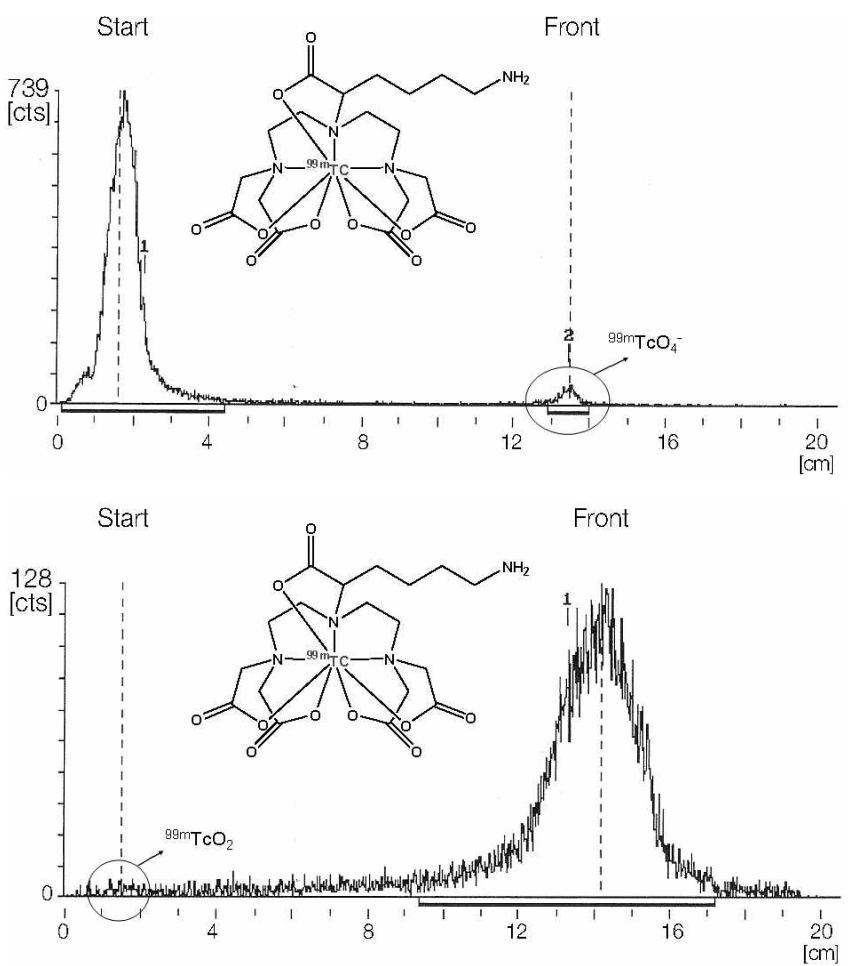

Higure 1. Radiochromatogram of lysine based I T $\mathrm{P}^{2} \Lambda$ complex; $\wedge$ Jioactive material binding site. Conditions: developing solvent(a) MFK. (b) $0.90^{\circ}$ saline stationary phase (ITIC-SG). starting point $(1.5 \mathrm{~cm}$ ). distance from solvent front (about $13 \mathrm{~cm}$ )

the origin. The amount of ${ }^{\mathrm{m}} \mathrm{TeO} \mathrm{C}_{2}$ was determined using saline to develop an IILC strip. In this system ${ }^{0 . \mathrm{Trl}} \mathrm{ICO}_{2}$ was retained at the origin, whereas iree ${ }^{99 \mathrm{II}} \mathrm{TeO}_{+}$and the labeled material moved with the solvent liont. The extent of the labeling was calculated as the following equation, the I'ILC test revealed a labeling yield of $98 \%$.

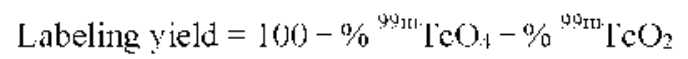

\section{Conclusion}

In summary, we deseribed a simple synthesis of a DTP $\Lambda$ derivative as a bifunctional chelating agent (BLCA). The prepared DTPA derivative can be applied lor the solid phase synthesis of peptides to develop peptide-based target radionuclide therapeutic agents. Furthenmore, bioconjugation with bioactive molecules, such as peptide will be implemented for the development of radioimmunotherapeuties or radioimm unodiannostics.

\section{References}

1. Hune. M.: Huanng 7.: I.: Bilgen, M.: Berkland, C. Nanomedicime: Vanotechnologn: Biology and Medicthe. 2008, 4, 30

2. Liu. S. Ach: Dirg. Delis Rev. 2008.60, 1347.

3. Yang. J. J: Yang. J.: Wei. L.: Zurkiya. O.: Yang. W.: Li. S.: Zon. I.: Maniccia, A. J.. W.: Mao, H.: \%hao, F.: Malchow, R.: Zhao. S.: Iolmsem, J.: Hu, Xiaoping: Krogstad, E.: I.iu, 7. R. J. Am. Chem. Soc. 2008. 130.9260

4. Yurt. A.: Karanci, N. J. Wol. Struct. 2008, 892.392

5. Schibli. R.: Schubiger. P. A. Lur J. Nicl. Hed Mol Imaging 2002, 29. 1529.

6. Mundwiler. S.: Waibel, R.: Spingler, B.: Kunze. S.: Nlberto. R. Hinct led Biol 2005, $32,473$.

7. Sunberg. M. W.: Meares, C. F.: Goodwin, D. A.: Diamanti, C. I. Nature 1974. 250, 587.

8. Sundberg. M. W.: Meares. C. F.: Goodwin. D. A.: Diamauti. C. I. Med. Chem. 1974. 17. 1304

9. Chikara. B. S.: Kumar. N.: Tandon. V.: Mishra. A. K. Bioorgan. Hed Chem. 2005, 13.4713

10. Schonher. T.: Seichter. W.: Weber. F. Polvhedron 2006, 25. 3463.

11. Schouher. T.: Weber, F.: Seichler, W. 7. Anorg. Ally. Chem. 2001, 627. 2420 .

12. Micderer, M.: Scheinberg. D. A.: MeDevitt. M. R. Ath: Drig. Detiv. Rev. 2008. 60. 1371

13. J.iang. X.; Parkinson, J. A.; Weishaupl, M: Ciould, R. O: Paisey. S. I.; Park, H. S.: Hunter, T. M.; Blindauer, C. A.; Parsm1s. S.: Sadler. P. J.J. .1m. Chem. Soc. 2002. 124. 9105

14. Choi. K. H.: Ifong. Y. D.: Pyun. M. S.: Choi. S. J. Bull Korean Chem. Soc. 2006. 27. 1194.

15. Andt. F. Org. Synh. 1934, 2, 165.

16. Pacuetle. I. A. Encyctopedia of reagents for organic snithesis $1995,2,1512$.

17. Martcll.A. E.: Snith, R. M. Critical Stability Constants: Plomm Press: New York. 1974: p 204. p 236, p 281

18. 7olle. I. Techmetium-99m Phamoceaticals Preparation and Onalin Control in fittckar Medicine: Springer: Berlin I Ieidelberg. New York. 2007: p 297-303. 